\title{
The Prosecution's Duty To Preserve Evidence Before Trial
}

While courts have adequately dealt with prosecutorial suppression of evidence, an acceptable response to the destruction or loss of relevant evidence has remamed elusive. When evidence has been suppressed, courts simply evaluate its probative value to determine whether a new trial is required. However, when evidence is lost or destroyed, a court must decide its materiality based only on the unsupported testimony of the parties. And if the evidence could have been exculpatory, the defendant will be severely disadvantaged even if a new trial is ordered, for a new trial cannot consider evidence that no longer exists.

Instead of using analyses developed in suppression of evidence cases, courts must develop a systematic and thorough method particularly designed to deal with lost or destroyed evidence. This Comment proposes a two-pronged prosecutorial duty to preserve evidence, ${ }^{1}$ and a remedy based on the presumed probative value of lost or destroyed evidence. Part I reviews the inadequate standards courts have used in the past to analyze destruction or loss of evidence cases. Part II sets out a new approach to analyzing the problems inherent im destruction or loss of evidence cases. It provides a standard to guide the government and the courts in deciding what evidence should be preserved. If these standards are not met, the trial court should proceed to the reinedy stage described in Part III by assuming the evidence exists in the form claimed by the defense.

The Unresolved Problems in Destruction or Loss OF Evidence CaSES

Courts have generally analyzed the destruction or loss of evidence under one of two existing standards. Some courts have based the decision to grant a new trial on the inateriality of the nnissing evidence. ${ }^{2}$ Others have focused on both the standard procedures used to preserve evidence and the good faith of the prosecution. ${ }^{3}$ These two approaches

1. This Comment only deals with destruction or loss of evidence cases in which both the prosecution and the defense agree on the prior existence of the evidence in question.

2. See, e.g., Lee v. United States, 368 F.2d 834 (D.C. Cir. 1966); Trimble v. State, 75 N.M. 183, 402 P.2d 162 (1965).

3. See, e.g., United States v. Augenblick, 393 U.S. 348 (1969); Killian v. United States, 368 U.S. 231 (196I). 
demonstrate courts' varying analyses and the receptiveness of the judicial system to a proposal more responsive to defendants' needs.

\section{A. The Materiality Standard}

\section{Development of the Standard}

The materiality standard was announced in the landmark case of Brady v. Maryland, ${ }^{4}$ a murder case in which the prosecution failed to disclose an extrajudicial statement of the defendant's accoinplice admitting that the accomplice had committed the actual killing. The defendant claimed the prosecution's suppression violated due process and he moved for a new trial because the withheld evidence was relevant to his attempt to avoid the death penalty. ${ }^{5}$ The Supreine Court agreed and ordered a new trial on the issue of punishment.

The Brady Court held "that the suppression by the prosecution of evidence favorable to an accused upon request violates due process where the evidence is niaterial either to guilt or to punishment, irrespective of the good faitl or bad faith of the prosecution." The Court further stated that the purpose of granting the defendant rehef is to guarantee a fair trial, not to punish the prosecution for its acts or omissions. $^{7}$

United States v. Agurs ${ }^{8}$ further refined the Brady materiality requirement. In Agurs, the Supreme Court held that the materiality requirement varies with three different situations. If the suppressed evidence reveals that the prosecution used perjured niformation, and the prosecution knew or should have known of the perjury, then the conviction must be set aside "if there is any reasonable likelihood that the false testimony could have affected the judgment of the jury." If the prosecution fails to disclose evidence specifically requested by the defense, the materiality standard is satisfied if the suppressed evidcnce "might have affected the outcome of the trial."10 If the defense either

4. 373 U.S. 83 (1963).

5. Id. at $84-85$.

6. Id. at 87 .

7. Id.

8. 427 U.S. 97 (1976).

9. Id. at 103.

10. Id. at 104. The Court held that, although the prosecution is not required to disclose everything specifically requested by the defense, any doubt should be resolved in favor of the defense:

Although there is, of course, no duty to provide defense counsel with unlimited discovcry of everything known by the prosecutor, if the subject matter of such a request is material, or indeed if a substantial basis for claiming inateriality exists, it is reasonable to require the prosecutor to respond either by furnishing the information or by subuniting the problein to the trial judge. When the prosecutor receives a specific and relevant request, the failure to inake any response is seldom, if ever, excusable.

Id. at 106. 
makes a general request for any exculpatory evidence or entirely fails to make a request, ${ }^{11}$ the materiality standard is satisfied "if the omitted evidence creates a reasonable doubt [about the defendant's guilt] that did not otherwise exist."12

A court using the Brady and Agurs materiality standard in a destruction or loss case must speculate on the significance of the missing evidence. Moreover, a court must balance these speculative effects agamst the incriminatimg evidence to determine whether the particular formulation of the materiality standard in question is satisfied. If the standard is satisfied, Brady and Agurs require a new trial. However, if the evidence is deemed immaterial, the conviction must stand.

\section{The Inadequacy of the Materiality Standard}

While useful im suppression of evidence cases, the materiahity standard is madequate for analyzing the fundamentally different case in which evidence is lost or destroyed. ${ }^{13}$ In a suppression case, the evidence is neither lost nor destroyed, but merely undisclosed. Its continued existence makes it relatively easy to determine on appeal whether its introduction at trial might have altered the outcome. However, if the evidence is lost or destroyed, the court must necessarily speculate not only about its significance, but also about its characteristics. ${ }^{14}$ Moreover, unlike suppression cases, simply granting a new trial in destruction or loss cases caimot resolve the problem; the defendant will still be unable to mtroduce the lost or destroyed evidence in the new trial.

The materiality approach also leads to unpredictable results in destruction or loss of evidence cases. The materiality test is an attempt to balance the prejudicial effect of suppressed evidence agamst the costs of a new trial. Though the cost of overburdening the courts is high, the

11. Id. at 107 .

12. Id. at 112 .

13. See, e.g., People v. Moore, 34 Cal. 3d 215, 221, 666 P.2d 419, 422, 193 Cal. Rptr. 404, 407 (1983); People v. Hitch, 12 Cal. 3d 641, 647-48, 527 P.2d 361, 365-66, 117 Cal. Rptr. 9, 13-14 (1974); Deberry v. State, 457 A.2d 744, $749-50$ (Del. 1983); Note, The Right to Independent Testing: A New Hitch in the Preservation of Evidence Doctrine, 75 Colum. L. REv. 1355, 1361 (1975); see also Comment, Judicial Response to Governmental Loss or Destruction of Evidence, 39 U. CHI. L. REv. 542, 557 (1972).

14. People v. Moore, 34 Cal. 3d 215, 221, 666 P.2d 419, 422, 193 Cal. Rptr. 404,407 (1983) ("II]t is the government's loss of evidence that requires speculative inquiry as to its materiality."); see also Note, supra note 13, at 1361; Comment, supra note 13, at 557. Although these two coinmentaries acknowledge that it is much more difficult to determine materiality once evidence is destroyed, they still argue that such a determination may be made in certain circumstances without making any assumptions about the evidence. This Comment takes the more extreme position that once the evidence is gone, a court inust necessarily speculate. Just because a court might actually reacl the correct result in certain instances does not cliange the fact that it is still adopting a "hit or miss" inquiry. 
social cost imposed by a judicial system that leads to incorrect results is even higher. Courts, therefore, have an incentive to grant new trials and many courts have struck the balance in favor of a low threshold of inateriahity in evidence suppression cases. ${ }^{15}$ Soine courts have imposed the burden of proving the defendant was not prejudiced by the suppression on the state. ${ }^{16}$

However, courts have been unable to respond similarly in destruction or loss cases. In such cases, a new trial in its traditional form has completely different implications. It loses any potential remedial effect because no new evidence will be introduced. Granting a new trial without inore simply cannot purchase a just result. Therefore, courts have little mcentive to order new trials in such cases and no uniformly

15. See, e.g., Anderson v. South Carolina, 709 F.2d 887, 888 (4th Cir. 1983) (suppression of autopsy and police investigation reports that were relevant to time of death "might have affected the outcome"); Monroe v. Blackburn, 607 F.2d 148, 151-52 (5th Cir. 1979) (failure to disclose viction's pretrial statement that did uot mention a noise at the door prior to the robbery, though the victim testified in court under cross-examination that there was a noise, was sufficient to create a reasonable likelihood that the suppressed pretrial statement could have affected the conviction); United States v. Sheehan, 442 F. Supp. 1003, 1008-09 (D. Mass. 1977) (although eyewitness did select defendant's photograph in two photographic spreads, suppression of eyewitness' statement in one of these interviews that he was not able to identify defendant as one of the bank robbers held sufficient to create a reasonable doubt that might have affected the outcone of the trial).

Instead of adopting a low standard of materiality, some courts have approached the problem by defining materiality broadly. See, e.g., Levim v. Katzenbach, 363 F.2d 287, 291 (D.C. Cir. 1966) (evidence that "might have led the jury to entertam a reasonable doubt about [defendant's] guilt" is material); Curran v. Delaware, 259 F.2d 707, 711 (3d Cir. 1958) ("pertinent facts relating to [the] defense" are material evidence); Griffin v. United States, 183 F.2d 990, 993 (D.C. Cir. 1950) ("evidence that may reasonably be considered admissible and useful to the defense" is material); see also Comunent, supra note 13 , at 548.

In Klein v. Harris, 667 F.2d 274 (2d Cir. 1981), the court stated:

Where, as here, the question whether the jury would have reached the same determimation in an error-free trial is open to reasonable doubt, the Supreme Court has directed the reviewing court not to speculate as to what the jury would have done had the error not been committed, but instead to reverse the conviction and order a new trial. That is all we have done here; we do not speculate as to what the jury would have done had the error not occurred or what the outcome of a new trial would be.

Id. at 291 (emphasis in original).

The preference for a broad definition of materiality can also be seen in Justice Marshall's dissent in Agurs, where he attacked the third formulation of the materiality standard in the case as being too high:

With all respect, this rule is coinpletely at odds with the overridimg imterest in assurimg that evidence tending to show innocence is brought to the jury's attention. The rule creates little, if any, mcentive for the prosecutor conscientiously to determine whether his files contaim evidence helpful to the defense. Indeed, the rule reinforces the natural tendency of the prosecutor to overlook evideuce favorable to the defense, and creates an incentive for the prosecutor to resolve close questions of disclosure in favor of conccalment. ...

....

... If there is a significant chance that the withheld cvidence, developed by skilled counsel, would have imduced a reasonable doubt in the minds of enough jurors to avoid a conviction, then the judgnient of conviction nust be set aside.

United States v. Agurs, 427 U.S. 97, 117, 119 (1976) (Marshall, J., dissenting).

16. See, e.g., Krantz v. State, 405 So. 2d 211, 213 (Fla. Dist. Ct. App. 1981). 
low threshold of materiality similar to that in suppression cases has been attamed. Courts have been prone to arrive at differing interpretations of materiality to suit fact-specific situations. As a consequence, materiality is an unpredictable legal principle in destruction or loss cases. ${ }^{17}$

\section{B. The Good Faith/Normal Procedures Standard}

\section{Development of the Standard}

Rather than employ the materiality analysis promulgated under Brady and Agurs, some courts have analyzed the good faith and nornal procedures of the prosecution in preserving evidence. In Killian $v$. United States, ${ }^{18}$ the landmark case in this area, the defendant was convicted for falsely denying his membership in the Communist Party. Because the statements of two witnesses were the key to the defendant's conviction, Killian moved for production of the notes made by FBI agents while interviewimg the witnesses. ${ }^{19}$ These notes were apparently lost. The Supreme Court ruled that there would be no violation of due process if the inforination in the notes were fully reflected in the final report, and therefore remanded the case to the district court to determime whether: the notes were made for the purpose of later incorporating or transferring them imto a final report; the imvestigators destroyed the notes in good faith; and the investigators observed and followed normal procedures of the investigative agency when they destroyed the notes. ${ }^{20}$

The Killian analysis generally has been apphed to "interim notes" cases. Typically in such cases, the prosecution introduces a final report into evidence after the preliminary notes used to prepare the final ver-

17. Courts in several destruction or loss cases have refused to find that the defendant has been prejudiced even though the missing evidence was pertinent to substantive issues of the case and could easily have been material. See United States v. Traylor, 656 F.2d 1326, 1334-35 (9th Cir. 1981) (defendant was convicted of conspiracy to import cocaine and the court refused to strike chemist's testimony based on four tests that the substance seized consisted of cocaine though the chemist admitted that none of these tests would alone be conclusive, and the substance was no longer available for retesting); Adkinson v. State, 611 P.2d 528, 533-34 (Alaska 1980) (police officer touched the barrel of the murder weapon and destroyed any possible fingerprints which might have been found there, the existence of which would have supported defendant's account of the events).

On the other hand, some destruction or loss cases have found that the defendant had been prejudiced because the missing evidence related to substantive issues. See, e.g., People v. Saddy, 84 A.D.2d 175, 445 N.Y.S.2d 601 (1981) (the destruction of tape recordings of defendant's dealings, despite the availability of other recordings, was sufficient to warrant rehief because it denied the defendant the opportunity to show he was acting innocently).

18. 368 U.S. 231 (1961).

19. Id. at 239.

20. Id. at 242 . 
sion have been lost or destroyed. ${ }^{21}$ However, the good faith/normal procedures standard has also been applied in other types of destruction or loss cases. Courts have generally been unconcerned with the specific significance of the destroyed or lost evidence. Rather, they have concentrated on the effort expended to preserve the evidence, and on screening out any inalice. ${ }^{22}$

\section{The Inadequacy of the Good Faith/Normal Procedures Standard}

As with the inateriality standard, the good faith/normal procedures approach inadequately responds to the harm suffered by defendants in destruction or loss cases. The defendant is denied an opportunity to test the accuracy of evidence introduced by the prosecution. ${ }^{23}$ The prosecution may have erred in transcribing the notes or results into the final report, or it may have maliciously altered the final report. Since the original evidence from which the results were prepared has been destroyed, the defendant can prove neither. ${ }^{24}$

21. See, e.g., United States v. Augenblick, 393 U.S. 348 (1969); United States v. Herndon, 536 F.2d 1027, 1029 (5th Cir. 1976).

22. See, e.g., California v. Trombetta, 104 S. Ct. 2528 (1984); United States v. Quintana, 673 F.2d 296, 298-99 (10th Cir.), cert. denied, 457 U.S. 1135 (1982).

23. In People v. Murtishaw, 29 Cal. 3d 733, 755, 631 P.2d 446, 458, 175 Cal. Rptr. 738, 750 (1981), the California Supreme Court noted the difficulty of verifying the prosecution's evidence:

The investigating officers preserved the results of [defendant's] interrogation through [the police investigators'] transcribed notes. The [investigators'] failure to record the interview and their destruction of the handwritten notes, lowever, nade it impossible for the defense to verify whether the typed transcript reflects the handwritten notes or the reality of the interrogation.

See also People v. Moore, 34 Cal. 3d 215, 666 P.2d 419, 193 Cal. Rptr. 404 (1983) (seientific testing); People v. Hitch, 12 Cal. 3d 641, 527 P.2d 361, 117 Cal. Rptr. 9 (1974) (breathalyzer sample).

24. See Hatfield v. State, 663 P.2d 987, 990-91 (Alaska Ct. App. 1983) (defendants' convictions for second-degree theft reversed because the state destroyed the object of the theft, thereby denying defendants the opportunity to weigh it independently and to assess its value); Municipality of Anchorage v. Serrano, 649 P.2d 256, 258-59 (Alaska Ct. App. 1982) (results of breathalyzer test suppressed because the prosecution failed to preserve a breath sample for independent testing); People v. Moore, 34 Cal. 3d 215, 220-21, 666 P.2d 419, 42 I, 193 Cal. Rptr. 404, 406 (1983) (court reversed a judgment revoking defendant's probation because his urine sample on which that judgment was based was destroyed, denying him the opportunity to impeach and verify test results); People v. O’Hearn, 142 Cal. App. 3d 566, 570-71, 191 Cal. Rptr. 481, 483-84 (1983) (court reversed defendants' convictions of possession of marijuana for sale because the state's destruction of nearly all the inarijuana denied defendants the opportunity to impeach and verify the quantity and quality of the marijuana); Garcia v. District Court, 197 Colo. 38, 47, 589 P.2d 924, 930 (1979) (court found a constitutional violation because the state destroyed defendant's breath sainple, rendering him unable to impeach or verify test results); Stipp v. State, 371 So. 2d 712, 713-14 (Fla. Dist. Ct. App. 1979) (court reversed the defendant's conviction because the prosecution destroyed contraband, thus denying defendant the opportumity to examine and test it imdependently); People v. Shepherd, 118 Misc. 2d 365, 367-69, 460 N.Y.S.2d 722, 724-25 (1983) (destruction of breath sample rendered further testing by defendant impossible and warranted suppression of breathalyzer test results); People v. McCann, 115 Misc. 2d 1025, 1029, 1032, 455 N.Y.S.2d 212, 215, 217 (1982) (failure to preserve blood sample and victim's clothing denied defendant an opportunity to verify and test the blood type, denying him due process of law). 
Moreover, the good faith/normal procedures standard is inadequate because it resolves problems of credibility in favor of the prosecution. Courts have tended to accept the prosecution's characterization of the events leading to destruction or loss unless it is clearly suspicious. $^{25}$ This judicial deference fails adequately to discourage the prosecution from maliciously or negligently mishandling evidence. Furthermore, the defendant has the insurmountable task of showing that the prosecution destroyed favorable evidence in bad faith where the evidence in question no longer exists. ${ }^{26}$

\section{The Need for A New Approach}

The aim of Brady v. Maryland" is "not punishment of society for misdeeds of a prosecutor but avoidance of an unfair trial to the accused." 28 Thus, in a suppression of evidence case, the prosecution's actions warrant a remedy only if it appears that the defendant might not have received a fair trial. Yet affording the defendant a fair trial demands consideration of the suppressed evidence. This presents no problem in suppression cases, however, because the evidence still exists. Indeed, the contmued existence of the evidence enables a court to weigh readily the significance of the suppressed evidence and therefore the degree to which the defendant has actually been harmed.

However, this attempt to reproduce a fair trial will fail when evidence has been lost or destroyed. ${ }^{29}$ In such a case, a court can only speculate about the potential sigmificance of the missing evidence. The trial judge must rely upon the allegations of the prosecution and the defense to determine if the missing evidence is significant enough that its absence prevented a fair trial. Furthermore, both the prosecution and the defense are equally able to mischaracterize items that no longer exist, and neither has the evidence necessary to disprove the other's

25. See United States v. Quintana, 673 F.2d 296, 298-99 (10th Cir.), cert. denied, 457 U.S. 1135 (1982); United States v. Hoppe, 645 F.2d 630, 633-34 (8th Cir. 1981) (finding no bad faith and excusing the failure to produce interim notes even though their destruction may have occurred after a specific request by defendant); United States v. Herndon, 536 F.2d 1027, 1029 (5th Cir. 1976) (requiring defendant to rebut the imphicit presumption of good faith); People v. Savage, 129 Cal. App. 3d 1, 3-4, 180 Cal. Rptr. 761, $762-63$ (1982); State v. Walters, 8 Kan. App. 2d 237, 241,655 P.2d 947, 951 (1983) (accepting the government's word that there was complete incorporation of interim notes and therefore excusing their nonavailability at trial); see also Comment, supra note 13, at 550, 558. For criticism of the judicial deference paid to governmental claims of good faith, see United States v. Harrison, 524 F.2d 421, 430-33 (D.C. Cir. 1975).

26. "In nearly every such [destruction of interim note] case, however, the only solid evidence a defendant could offer to show either bad faith or failure to transfer all data would come from producing the notes themselves-exactly the course he cannot pursue because of the agency's practice." United States v. Harrison, 524 F.2d 421, 432 (D.C. Cir. 1975).

27. 373 U.S. 83 (1963).

28. Id. at 87.

29. See supra text accompanying notes 13-14. 
claim..$^{30}$

The impossibility of restoring the defendant to his original position defeats a Brady-based atteinpt to achieve satisfactory results in destruction or loss cases. ${ }^{31}$ Likewise, the good faith/norinal procedures standard does not provide an appropriate solution, since it unfairly resolves probleins of credibility in favor of the prosecution. An optimal solution must eliminate the unfairness to the defendant, yet provide a strong imcentive to the government to preserve evidence vital to the defense.

\section{II}

\section{Proposed Standards for Preserving Evidence}

While a court can speculate about the significance of a piece of evidence, its true utility can be determined only after both the prosecution and the defense have examined it. When the government fails to preserve evidence before the defense has had an opportunity to examine it, the defendant loses the ability to explore its possible utility to him. The introduction of results prepared froin the prosecution's examination of the evidence does not resolve this problem. The defense caimot impeach the accuracy or truthfulness of the results without the original evidence.

Yet the mandate of Brady requires evidentiary procedures that ensure a fair trial. At a minimum, the accused must be allowed to examine all evidence favorable to his defense. To this end, the government must be encouraged to exercise greater care in preserving evidence. By failing to discourage the government from losing or destroying evidence, the judicial system is in effect encouraging the prosecutor to choose the defendant's evidence. Yet allowing the prosecution to decide what is inaterial for the defense is uniformly disapproved. ${ }^{32}$

Ideally, the prosecution should preserve all evidence at the crime

30. Id: see also United States v. Tariq, 521 F. Supp. 773, 786 (D. Md. 1981) (holding that because of deportation of potential witnesses, it is impossible to know with certainty whether witnesses would have helped defendant's case).

31. See State v. Wright, 87 Wash. 2d 783, 795, 557 P.2d 1, 9 (1976) (Wright, J., concurring).

32. See, e.g., United States v. Robinson, 546 F.2d 309, 312 (9th Cir. 1976), cert. denied, 430 U.S. 918 (1977); United States v. Harris, 543 F.2d 1247, 1248 (9th Cir. 1976); United States v. Harrison, 524 F.2d 421 (D.C. Cir. 1975). Moreover, allowing the prosecution to lose or destroy evidence renders the duty to disclose illusory. The court in United States v. Bryant, 439 F.2d 642 (D.C. Cir. 1971), held that:

It is most consistent with the purposes of those safeguards to hold that the duty of disclosure attaches in some form once the Government has first gathered and taken possession of the evidence in question. Otherwise, disclosure might be avoided by destroying vital evidence before prosecution begins or before defendants hear of its existence. . . . Only if evidence is carefully preserved during the early stages of investigation will disclosure be possible later.

Id. at 651; see also People v. Saddy, 84 A.D.2d 175, 178, 445 N.Y.S.2d 601, 604 (1981). 
scene. It is impossible to predict the theory of a case before the investigation is coinplete and at such an early stage any evidence could turn out to be relevant. However, in a world of scarce judicial resources, preservation of all evidence is an unreahstic goal. The critical issue is where to draw the line between what should be preserved and what may be discarded.

An ideal preservation of evidence standard must strike a realistic balance between the effect of missing evidence on the defendant's case and the cost of a new trial. The standard must also reflect the burden on the government at the various stages of the investigative process. For example, a requirement that the government preserve all conceivable evidentiary objects at the earliest stages of investigation would in effect require the government to impound the entire crime scene. Such a solution is impractical and excessively costly. On the other hand, once the government agent has decided that an item has possible relevance to a criminal prosecution, resources have already been committed to screening out and preserving that evidence. Few additional burdens are mcurred by requiring the government to preserve the itein until the defense has been able to examine it as well. It is by reference to these two stages that the government's duty to preserve should vary.

\section{A. The Crime-Scene Stage}

The crime-scene stage encompasses the investigation of the crime at its site. When an investigator evaluates the evidence at the scene of the crime he may retain some evidence and discard the remainder because he believes it will not be pertinent to either side at trial. If the defendant subsequently argues that the discarded evidence would have exculpated him or helped corroborate his story, the court is faced with a dilemma: while the court does not want to deny the defendant any opportunity to exculpate himself, it cannot impose upon investigators the duty to preserve every item at the scene of a crime.

Resolving this dilemma between fairness and practicality requires a standard to determine which evidence discovered at the crime scene should be preserved. The appropriate standard demands that the prosecution preserve the evidentiary itenis that a reasonable agent would preserve-that is, any evidence which could reasonably be expected to be relevant to the case. ${ }^{33}$ Indeed, it is best to define an investigator's

33. A piece of evidence can be significant either because of the type of evidence it is or because of its individual characteristics. For example, no one would dispute the potential significance of a gun found at a crime scene next to a gunshot victim, but a lamp standing near a victim with a cracked skull becomes significant only when evidentiary characteristics such as blood traces are found on it.

Indeed, some courts have required the preservation of evidence that could reasonably be expected to be pertiment to the case later. See United States v. Bryant, 439 F.2d 642, 648 (D.C. 
duty as preserving evidence that may be reasonably foreseen as significant because such evidence is most likely to be relevant to the case as it later develops.

The reasonable person standard depends on the actions of a reasonable investigator under the circumstances and, thus, the court's decision hinges on a difficult line to draw. The reasonableness of each investigator and the circumstances of each case will vary widely. Nevertheless, the reasonable person standard is used in other areas of the law ${ }^{34}$ without msurmountable difficulties, despite similar line-drawing problems.

Furthermore, in addition to providing a guideline for imvestigators, the reasonable person standard conserves prosecutorial resources. The prosecution's decision to preserve a piece of evidence will depend on how it believes a court will characterize the evidence at trial. The prosecution can avoid sanctions by simply preserving all evidence it predicts the court will deem pertinent to the case. Of course, the task of line drawing may leave the prosecution unsure about how a court will characterize a particular piece of evidence. If the prosecution is risk averse, it should preserve such evidence. ${ }^{35}$ The reasonable person standard, however, does not force the prosecution to attempt the excessively burdensome task of preserving all evidence at the crime scene.

Moreover, the costs associated witl preserving unnecessary evidence will diminish over tine. As investigators become more experienced at predictimg which evidence may be reasonably deemed relevant, they will find it easier to predict a court's subsequent characterization. Since experience reduces uncertaimty, the burden of preserving evidence that a court later rules irrelevant will decrease.

\section{B. The Post Crime-Scene Stage}

At the post crime-scene stage, the government has retamed evidence it deemed pertinent when investigating the crime scene. If the prosecution fails to give the defendant an opportumity to examme this evidence before its destruction, the defendant may suffer irreparable prejudice. Thus, the prosecution must preserve evidence at the post crime-scene stage as well. At this stage, however, a stricter standard for

Cir. 1971) (evidence by its nature highly material to the case should be preserved); Hatfield $v$. State, 663 P.2d 987, 990 (Alaska Ct. App. 1983) (reversal of convictions because government agent should have realized that the weight of copper was material to a case imvolving theft, and such copper should have been preserved); People v. Hitch, 12 Cal. 3d 641, 647, 527 P.2d 361, 365-66, 117 Cal. Rptr. 9, 13-14 (1974) (evidence affecting the credibility of highly matcrial evidence should be preserved); People v. Gonzales, 156 Cal. App. 3d 558, 562, 203 Cal. Rptr. 38, 40 (1984).

34. For example, the reasonable person standard is used extensively in tort law. See W.P. Keeton, D. Dobbs, R. Keeton \& D. OWen, The Law of Torts 173-93 (5th ed. 1984).

35. See United States v. Agurs, 427 U.S. 97, 108 (1976). 
the preservation of evidence is appropriate. Since the inarginal cost of preserving evidence already retained is generally low, a stricter standard will not impose excessive burdens on the prosecution. Moreover, it is relatively easy to provide the defendant with an opportunity to identify any of the retained evidence that might prove beneficial to his case. The process of giving the defendant the opportunity to examine the evidence before destruction is called the notice-petition method.

\section{The Notice-Petition Method}

The disadvantage associated with lost or destroyed evidence is amehorated if the defendant has been afforded a prior opportunity to examine it. Therefore, the prosecution should give the defense a period of time in which to examine all evidence collected at the crime scene. "[D]estruction of evidence [should] follow only after petition and order directed to the particular items to be destroyed, with notice to the defendant and opportunity to petition for access to that which has been seized."36 The prosecution can employ this method when the quantity of evidence is so large that it would be extremely expensive or difficult to store it for a long period of time, ${ }^{37}$ or when the prosecution believes the evidence is valueless.

Several benefits accrue from employing the notice-petition method. First, some evidence may be destroyed under limited, controlled circumstances, thus reducing the administrative costs of storage. While notice to the defendant may be burdensome because it involves identifying and storing each item, the amount of evidence imvolved at the post crime-scene stage is already inore manageable than at the crime-scene stage. Second, the defendant cannot reasonably argue the unfairness of destruction or loss of evidence if he fails to avail limiself of an opportunity to examine the evidence imdependently. These benefits strike the proper balance between the defendant's interest im a fair trial and the prosecution's interest in prompt and final adjudication. If the prosecution has employed the notice-petition method, it should be free to discard or destroy evidence. If it fails to notify the defense, the defendant should be accorded appropriate relief.

\section{An Absolute Duty to Preserve Evidence}

Without prior notice to the defendant, the prosecution cannot de-

36. United States v. Heiden, 508 F.2d 898, 903 (9th Cir. 1974) (Merrill, J., concurring).

37. See, e.g., United States v. Heideu, 508 F.2d 898 (9th Cir. 1974); People v. O'Hearn, 142 Cal. App. 3d 566, 191 Cal. Rptr. 481 (1983).

Analogously, the notice-petition nethod is appropriate in illegal alien transportation cases where it is both unfair and expensive to detain individuals for a lengthy period of time. See United States v. Valenzuela-Bernal, 458 U.S. 858, 877 (1982) (O'Cormor, J., concurring); United States v. Tariq, 521 F. Supp. 773, 785 (D. Md. 1981). 
stroy evidence. If the government fails to use the notice-petition method, courts should impose an absolute duty to preserve all evidence collected at the crime scene. An absolute duty includes no good faith exceptions; the defendant has suffered no less harm when the government loses or destroys evidence in good faith. Rather, justice demands that any remedy must depend only on the possible effect of the missing evidence. Thus, an automatic sanction should apply regardless of the reason for the government's failure to preserve evidence. If evidence is destroyed without notice, or lost, ${ }^{38}$ the defendant must be afforded automatic relief.

Yet automatic relief does not necessarily mean mandatory dismissal. Ratler, the scope of the relief will depend on the possible relevance of the absent evidence. At a minimum, violation of an absolute duty to preserve evidence must lead to a new trial if the case is at the appellate level, and shift the burden to the prosecution to disprove a presumption of materiality if the case is at the trial level..$^{39}$

Automatic relief at the post crime-scene stage prevents the government from cloosing the defendant's evidence. ${ }^{40}$ It provides an imcen-

38. Of course, if the prosecution loses evidence, it will undoubtedly violate the notice-petition method.

39. See infra Part III.

40. Many courts have granted relief without requiring the defendant to demonstrate that he was prejudiced by the destruction of evidence at the post crime-scene stage. For example, in Lee v. United States, 368 F.2d 834 (D.C. Cir. 1966), the defendant was convicted of selling narcotics in the presence of both government undercover agents and other eyewitnesses who later testified for the government. After the arrest, the drugs in question were delivered to a police officer by the agent who allegedly purchased them from the defendant. The officer had prepared written reports of his dealings with the agent, but the reports were destroyed before trial. The officer was therefore unable to recount accurately the nature of those dealings and whether other packages had been dehvered as well. Id. at 837 . The defendant's conviction was reversed and the officcr's testimony stricken. $I d$. at 838 .

In Trimble v. State, 75 N.M. 183, 402 P.2d 162 (1965), the defendant was convicted of firstdegree murder. He argued that shooting the deceased was an act of self-defense because the deceased attempted to harm him with a coffee table. This attack was allegedly proinpted by the defendant's accusations that the deceased had repeatedly made sexual advances towards the defendant's wife. The defendant further claimed that lie had written a letter to a third party and had made tape recordings which tended to show that sexual advances were aetually made. Id. at 18587, 402 P.2d at 164-65. Because the prosecution appeared to have tampercd with the tapes and lost the defendant's letter, the court set aside the sentence. Id. at 191, 402 P.2d at 168. The court noted that the defendant had been left in a vuhrerable position because it was inpossible for him to corroborate his story, and the jury was presented with a one-sided police statement that the letter and tapes were irrelevant to the defense. Id. at 188-89, 402 P.2d at 166 .

See also People v. O'Hearn, 142 Cal. App. 3d 566, 569, 191 Cal. Rptr. 481, 483 (1983) (rehef granted where the government destroyed evidence even though it considered the evidence pertinent enough to photograph and sample); People v. Holloway, 649 P.2d 318, 320 (Colo. 1982) (sanction imposed on the prosecution for its failure to preserve a tape it had preserved imitially, but later destroyed on a claim of administrative inconvenience); Deberry v. State, 457 A.2d 744, 753 (Del. 1983) (pohice liave a duty to preserve vital evidence); People v. McCaım, 115 Misc. 2d $1025,1031-32,455$ N.Y.S.2d 212, 216 (1982) (destruction or loss of evidence that could have exculpated the defendant with absolute certainty warrantcd relief where the police recognized its im- 
tive for the government to preserve as carefully as possible any evidence it has taken into its custody. And it does so without wasting both government and judicial resources, since retaining evidence until the defense has examined it is only marginally more burdensome than gathering it at the crime scene in the first place.

An absolute duty to preserve post crime-scene evidence finds support in both lower federal courts and in state courts. However, the United States Supreme Court has shown reluctance to validate this trend in certain areas.

\section{a. Judicial Acceptance of an Absolute Duty}

Some lower federal courts have consistently proinoted the preservation of evidence at the post crime-scene stage. For example, in United States v. Bryant, ${ }^{41}$ the District of Colunibia Circuit held that the intentional, but nonmahicious, destruction of any evidence relevant to the defense violated due process. ${ }^{42}$ The court concluded that the destruction or loss of relevant evidence can only be excused if two conditions are satisfied. First, the government nuust proinulgate rigorous and systematic rules to preserve all relevant evidence. Second, the agent must attempt in good faith to coiniply with these rules. The government has the burden of proving the satisfaction of these conditions. ${ }^{43}$

Bryant approaches an absolute preservation standard for all post crime-scene evidence. While the good faith exception reflects a view that it is unfair to grant relief if the government has not been at fault, ${ }^{44}$ in practice it will be satisfied only under narrow circumstances. To determine the apphicability of the good faith exception, a court inust look to the testimony of the agents themselves. However, a court following Bryant will be skeptical because the preservation requireinent has already been violated and any testimony concerning the government's actions is likely to be self-serving. The good faith exception will be narrowly limited to externally verifiable events that clearly indicate the unavoidability of destruction.

In United States v. Harrison, ${ }^{45}$ the District of Columbia Circuit

portance and preserved it initially). But see People v. Newsome, 136 Cal. App. 3d 992, 1001-02, 1006, 186 Cal. Rptr. 676, 681, 684 (1982) (failure to prevent the deterioration of evidence excused because the defendant did not avail himself of the opportunity granted by the prosecution to test the evidence).

41. 439 F.2d 642 (D.C. Cir. 1971).

42. Id. at 648 .

43. Id. at 652 .

44. See Note, Criminal Procedure: Government Has Duty to Implement Effective Guidelines to Preserve Discoverable Evidence, 1971 DUKE L.J. 644, 652 (there may be no satisfactory solution where the prosecution has tried in good faith to preserve evidence pursuant to Bryant and still loses it).

45. 524 F.2d 421 (D.C. Cir. 1975). 
strengthened the Bryant rule as applied to pretrial witness notes. The court required the prosecution to preserve rough notes of pretrial interviews with potential witnesses, whether or not the witnesses eventually testified. The court considered these notes potentially $\mathrm{Brad}^{46}$ material and granted the defendants rehef without any showing of actual prejudice.

The Harrison rule imposes an absolute duty to preserve pretrial witness notes from interviews taken by the government. The notes must be preserved so that the court, rather than the prosecution, may decide whether they are relevant evidence. ${ }^{47}$

More recently, in United States $v$. Tariq, ${ }^{48}$ a federal district court imposed an absolute duty on the government to refrain from deporting previously interviewed eyewitnesses. The court found that deporting such witnesses can only prejudice the defendant, and required the prosecution to overcome a presumption of prejudice. Such a presumption is automatic upon violation of this duty. In addition to Tariq, various circuit courts have also granted automatic rehef where the government has rendered potentially relevant witnesses unavailable to the defense before trial. ${ }^{49}$

California also appears to have mandated absolute preservation of any evidence collected at the crime scene. In People v. Hitch, ${ }^{50}$ the California Supreme Court found the destruction of a breathalyzer sample imperimissibly prejudiced a drunk driving defendant. The court held that the results from the breathalyzer test by their nature were relevant to the defense and therefore it was improper to deny the defendant a chance to verify the test's accuracy. ${ }^{51}$

Following United States v. Bryant, ${ }^{52}$ Hitch allows an exception for

46. Brady v. United States, 373 U.S. 83 (1963). See supra text accompanying notes 4-7.

47. See supra note 32 .

48. 521 F. Supp. 773 (D. Md. 1981).

49. See, e.g., United States v. Calzada, 579 F.2d 1358, 1362 (7th Cir. 1978) ("[T]he [d]efendant need not show prejudice to his or her case arising from the government's violation of the right to compulsory process by deporting eyewitnesses to the crime at issue."); United States v. Mendez-Rodriguez, 450 F.2d 1, 5 (9th Cir. 1971) (defendant need not show prejudice before relief is granted because the prosecution violated due process by hindering defendant's ability to prepare his defense); Bray v. Peyton, 429 F.2d 500, 501 (4th Cir. 1970) ("Even if not deliberate, the prosecuting official obviously obstructed the defendant's offer of exculpatory proof. A blow to our adversary system, it was inherently prejudicial."). For state court treatınent of the deportation of eyewitnesses, see People v. Mejia, 57 Cal. App. 3d 574, 129 Cal. Rptr. 192 (1976) (deportation of eyewitnesses to crime after the government initially took them into custody denied defendant a fair trial).

50. 12 Cal. 3d 641, 527 P.2d 361, 117 Cal. Rptr. 9 (1974).

51. Id. at 647,527 P.2d at 365, 117 Cal. Rptr. at 13. However, the court reversed tlie judgment below on the ground that its ruling was to have only prospective apphication. Id. at 655,527 P.2d at 371, 117 Cal. Rptr. at 19.

52. 439 F.2d 642 (D.C. Cir. 1971). See supra text accompanying notes 41-44. 
good faith attempts to preserve evidence. However, such an exception is applicable only in the very small number of cases in which the prosecution's good faith is objectively verifiable. ${ }^{53}$ Indeed, so narrow is the exception that some cases following Hitch have done away with it. ${ }^{54}$ Once agaim, the operational effect of the court's rule is an absolute preservation standard for any evidence initially collected at the crime scene.

\section{b. The Supreme Court Approach}

Despite this acceptance in the lower federal courts and in the state courts, the United States Supreme Court has been reluctant to validate an absolute duty to preserve post crime-scene evidence. For example, the Supreme Court recently questioned the Hitch rule in California $\nu$. Trombetta. ${ }^{55}$ Relying on Killian v. United States, ${ }^{56}$ the Court ruled that police officers had acted in good faith in destroying a breath sample after a drunk driving test. ${ }^{57}$ Since the test has proven to be highly reliable, the Court concluded that preservation of the breath sample would only tend to confirm the test results. Finally, the Court considered the availability of the agents for cross-examination significant. ${ }^{58}$ Thus, the defendant's due process rights were not violated when the sample was unavailable at trial.

In Trombetta, the Supreme Court resurrected the good faith/normal procedures standard of the interim note cases. ${ }^{59}$ However, in doing so, the Court created a large loophole. The good faitl exception permits the government maliciously or negligently to destroy evidence potentially favorable to the defendant. Moreover, the Court accepted the government's good faith without question, and described the defendant's concern as limited to the reliability of the testimg equipinent. Yet this facile determination ignores the possibility of an improperly conducted test or a inischaracterization of the test results by the officers. Without the evidence, the defendant cannot attack the test results. Cross-examination of the arresting officer at trial is madequate; if he

53. See supra text following note 44 .

54. See, e.g., Garcia v. District Court, 197 Colo. 38, 47, 589 P.2d 924, 930 (1979), in which the court stated:

We hold, therefore, that in all cases where a defendant elects to submit to a breath test to determine his blood alcohol level, he inust be given a separate sample of his breath at the time of the test or the alcohohc content of his breath in a inanner which will permit scientifically reliable independent testing by the defendant, if that test is to be used as evidence.

55. 104 S. Ct. 2528 (1984).

56. 368 U.S. 231 (1961). See supra notes 18-20 and accompanying text.

57. Trombetta, $104 \mathrm{~S}$. Ct. at 2534.

58. Id. at 2535 .

59. See supra text accompanying notes $18-26$. 
incompetently conducted the test, he would not be aware of it. And if he lied about the results he would not admit it..$^{60}$

In another recent Supreme Court decision, United States $v$. Valenzuela-Bernal, ${ }^{61}$ the defendant was charged with harboring three illegal ahens. Two of the aliens were deported after being questioned by the government, and the defendant objected that he was denied his opportunity to interview the alien witnesses. Since knowledge of the ahens' immigration status was an element of the crime, he argued that they should have been present for questioning.

The Court disagreed, holding that the defendant had failed to present some plausible way in which the aliens' testimony could have been material or favorable to his defense. ${ }^{62}$ The holding rested heavily on Congress' policy of swift deportation. Moreover, the Court found that its rule avoided both financial and physical burdens on the government and emotional strain on alien witnesses. ${ }^{63}$

Valenzuela-Bernal suffers from the same inadequacies as Trombetta. Even if the financial and physical burdens on the government and witnesses are heavy, ${ }^{64}$ they are still insufficient to overcome the defendant's important constitutional right, which has been acknowledged by the Court, ${ }^{65}$ to material eyewitness testimony. A more appropriate approach is to relieve the government's burdens by alternatives less imtrusive upon defendants' rights. For example, as Justice O'Connor suggested in her concurrence, the government could detain witnesses long enough for both sides to interview them. ${ }^{66}$

But Valenzuela-Bernal strikes the balance in favor of the government. As Justice Brennan observed in his dissent, the Court has effectively allowed the government, rather than the defendant, to determme

60. The court in United States v. Harrison, 524 F.2d 421 (D.C. Cir. 1975), recognized the weakness of cross-examination as a reinedy:

Without the [interim] notes, which, of course, would be the best evidence, he is reduced to trying to show a discrepancy in the . . . report by cross-exaunining the witness who was the subject of the interview, a witness who was prepared for testifying, not by reading the rough notes, but by using the . . . report. There could hardly be a less auspicious setting for eliciting testimony that will cast doubt on the accuracy of the interview report. Cross-examining the agent will be no inore helpful. If there was an honest mistake in preparing the . . . report, one that escaped the agent when he rechecked the report, it is most unlikely that he will suddenly recall the error on the stand. If any discrepancy was the result of misunderstanding or deliberate action, the agent plainly is the nost unlikely source of that infornation.

Id. at 432 (footnote omitted).

61. 458 U.S. 858 (1982).

62. Id. at 874 .

63. Id. at 864-66.

64. The Court stressed swift deportation, conservation of government resources, and emotional strain on witnesses so heavily that it is not clear whether the Court would have reached a different result in a nonalien context.

65. 458 U.S. at 873.

66. Id. at 877 (O'Connor, J., concurring). 
the materiality of testimony. ${ }^{67}$ This judicial deference to the government completely ignores both the defendant's need and his constitutional right to prepare his defense. It also does not present a convincing case agamst an absolute duty to preserve all evidence collected at the crime scene.

In contrast to the Supreme Court approach, the cases in state and lower federal courts mandating automatic remedies for the destruction or loss of retained evidence more adequately serve the nceds of defendants and encourage the prosecution to handle evidence properly. The Court's failure to address the defendants' needs hampers their constitutional right to exculpatory evidence clearly established by Brady.

Automatic relief is a necessary response to government actions that render the Brady mandate ineffective. Furthermore, the loss or destruction of evidence is potentially more liarmful than suppression because evidence that no longer exists cannot be examined for inateriality. Therefore, development of an appropriate remedy is critical.

\section{III}

\section{A Remedy for the Prosecution's Failure To Preserve Evidence}

This Comment has thus far focused on formulating a duty to preserve evidence at the crime-scene and post crime-scene stages. As set forth above, a duty to preserve evidence is necessary to prevent the government from neglectmg its responsibility to safeguard evidence potentially relevant to the ensumg criminal trial. Therefore, if the standards for preserving evidence are not inet, the courts should automatically grant relief regardless of the actual prejudice to thc defendant. The parameters of the remedy, however, must be carefully defined.

\section{A. Remedies Under Existing Law}

Courts presently have broad discretion to select an appropriate remedy if evidence is lost or destroyed. ${ }^{68}$ However, since the evidence no longer exists, it is not possible to follow Brady by granting a new trial and exposing the suppressed evidence. Courts have, therefore, developed various other remedies including suppression of the results prepared froin the destroyed or lost evidence, automatic dismissal of the case, and mstructions to the jury requiring adverse inferences from the destruction or loss of the evidence. Since suppression of derivative

67. Id. at 884-85 (Brennan, J., dissenting).

68. See, e.g., People ex rel. Gallagher v. Distriet Court, 656 P.2d 1287, 1293 (Colo. 1983); People v. Holloway, 649 P.2d 318, 320 (Colo. 1982); State v. Smith, 650 S.W.2d 5, 7 (Mo. Ct. App. 1983). 
results and adverse inferences both require new fact finding, appellate courts using these approaches must remand destruction or loss cases to the trial court for further proceedings or a new trial. Despite this opportunity for a new trial, these remedies and automatic dismissal provide inadequate protection for defendants if evidence is lost or destroyed.

\section{Suppression of the Evidence}

Where the government has prepared reports froin evidence subsequently lost or destroyed, ${ }^{69}$ soine appellate courts have ordered trial courts to conduct a new trial without examining the results of those reports. ${ }^{70}$ Yet suppressing evidence at trial appears to provide inadequate protection for the defendant and does not punish the prosecution for its behavior.

The suppression reinedy has limited application in destruction or loss of evidence cases. First, suppression is a ineaningless tool if the prosecution takes the evidence into its custody but fails to prepare results froin it before the evidence is lost or destroyed, or if the prosecution improperly discards evidence at the scene of the crime. Second, even if the prosecution does imtroduce soine form of the original evidence, suppressing the results prepared from this evidence still denies the defendant an opportunity to use the evidence. Therefore, because of its own mistakes, the prosecution not only denies itself the opportunity to use a piece of evidence to its advantage, it also unfairly denies the defense that opportunity.

\section{Automatic Dismissal}

Recognizing the unfairness of the suppression reinedy, soine courts have held that the case inust be automatically dismissed despite other strong inculpatory evidence. ${ }^{71}$ The simplicity of this approach also reveals its flaws, and automatic dismissal is generally disfavored by the courts. ${ }^{72}$ Tliough sucl a reinedy would guarantee inaximunı deterrence, it cannot be justified on fairness grounds because it com-

69. See, e.g., People v. Hitch, 12 Cal. 3d 641, 527 P.2d 361, 117 Cal. Rptr. 9 (1974).

70. United States v. Well, 572 F.2d 1383, 1385 (9th Cir. 1978); United States v. Parker, 549 F.2d 1217, 1224 (9th Cir.), cert. denied, 430 U.S. 971 (1977); Municipality of Anchorage v. Serrano, 649 P.2d 256, 261 (Alaska Ct. App. 1982); People v. Moore, 34 Cal. 3d 215, 223-24, 666 P.2d 419, 423, 193 Cal Rptr. 404, 408 (1983); People v. Hitchl, 12 Cal. 3d 641, 653, 527 P.2d 361, 370, 117 Cal. Rptr. 9, 18 (1974); People v. O'Hearn, 142 Cal. App. 3d 566, 571, 191 Cal. Rptr. 481, 484 (1983); Garcia v. District Court, 197 Colo. 38, 47, 589 P.2d 924, 930 (1979); see also People v. Shepherd, 118 Misc. 2d 365, 369-70, 460 N.Y.S.2d 722, 725 (1983).

71. See, e.g., People v. Saddy, 84 A.D.2d 175, 180, 445 N.Y.S.2d 601, 605 (1981) (suppression insufficient, reversal of conviction more appropriate).

72. See, e.g., People v. Holloway, 649 P.2d 318, 320-21 (Colo. 1982). 
pletely ignores the possible significance of the discarded evidence. The lost or destroyed evidence might not necessarily have exonerated the defendant, but may have merely constituted circumstantial evidence tending to support the defendant's version of the facts. By granting automatic dismissal, courts confer a benefit on the defendant that he could not possibly have gamed had the evidence been available at trial. Dismissmg the case gives the defendant more than he requests.

\section{Adverse Inferences Against the Prosecution}

Some appellate courts have ordered the trial court to conduct a new trial and to permit the jury to draw adverse inferences against the government concerning the unavailability of the evidence. Therefore, juries are sometimes imstructed that they are to assume that the evidence, if available, would have been "favorable" to the defense and "unfavorable" to the prosecution. ${ }^{73}$ This remedy is an improvement over suppression of the evidence because it properly recognizes that before examination, evidence can help either the defense or the prosecution. However, rather than smiply denymg the prosecution an opportunity to use the evidence, a court granting this remedy actually favors the defendant.

The weakness of the adverse-inference remedy lies in its imprecision. Although it recognizes that the missing evidence is potentially favorable to the defendant as well as the prosecution, it fails to fashion a guideline that the jury can follow. The standard of "favorableness" is so broad that juries are likely to interpret it inconsistently. If a distillation of the missing evidence, such as a scientific report, is the only evidence used to convict the defendant, the inference will probably lead to dismissal regardless of how juries choose to interpret the standard. However, if other evidence is used to convict the defendant, a jury's interpretation of "favorableness" can be critical. Jurors inay be subconsciously prejudiced by other inculpatimg evidence and, therefore, adopt a limited interpretation of the standard or ignore it completely. By considering only one side of the scale, the jury is likely to skew the balancing process.

The optimal solution to destruction or loss of evidence cases must resolve the vagueness inherent in the adverse-inference approach. If juries have a comprehensible standard to apply, then the objections to the adverse-inference approach evaporate. Moreover, such an ap-

73. See United States v. Marques, 600 F.2d 742, 748 (9th Cir. 1979), cert. denied, 444 U.S. 858, 444 U.S. 1019 (1980); People v. Holloway, 649 P.2d 318, 320 (Colo. 1982) (option to draw adverse inferences); State v. Hamele, 449 A.2d 1020, 1024 \& n.5 (Conn. 1982); Deberry v. State, 457 A.2d 744, 754 (Del. 1983); People v. Hawn, 99 Ill. App. 3d 334, 339, 425 N.E.2d 1024, 1028 (1981); 2 J. Wigmore, EvidenCE § 291, at 228 (Chadbourn rev. ed. 1979). 
proach resolves the materiality of lost evidence by placing the burden on the prosecution to disprove favorable materiality. Thus, evidentiary questions are resolved on a proper basis-the materiality of the missing evidence-and the burden is placed on the traditional side in the criminal prosecution-tlie government.

\section{B. The "Presumed Characteristics" Approach}

To reduce the vagueness in the adverse-inference remedy, courts should employ the "presumed characteristics" approach. Instead of $\mathrm{m}$ structing the jury that the destroyed evidence would have been "favorable" to the defense, courts should establisln a presumption" that the evidence lad certam presumed characteristics. ${ }^{75}$ The "presumed characteristics" approach improves the "adverse-inference" remedy by abandoning a standard subject to differing interpretations in favor of one that firmly establishes specific characteristics.

Under the presumed characteristics remedy, the nature of the missimg evidence can be defined by relying upon either the prosecu-

74. There are three types of presumptions. The conclusive presumption irrebuttably establishes a fact. See MCCORMICK ON EvidenCE § 342, at 966 (E. Cleary ed. 1984); see also People v. Zamora, 28 Cal. 3d 88, 615 P.2d 1361, 167 Cal. Rptr. 573 (1980) (conclusive presumption sanction for destruction of evidence). Such a presumption is overly deferential to the defendant as it completely ignores the evidence that the prosecution might be able to offer in rebuttal.

On the other extreme is Professor Thayer's approach, which views the sole effect of a presumption as shifting the burden of producing evidence with regard to the presumed fact. Once any evidence is introduced showing the nonexistence of the presumed fact, the presumption disappears. Id. $\$ 344$, at 974 . Professor Thayer's theory has been codified in CAL. EvID. CODE $\$ 604$ (West 1966). This type of presumption is also unsatisfactory because any offer of rebuttal evidence, no matter how weak, will overcoine the presumption.

A more appropriate type of presumption for the presumed characteristics approach is found in CAL. EvID. CODE $\$ 606$ (West 1966). Such a presumption affects the government's burden of proof, requiring it to show the nonexistence of the presumed fact by the requisite degree of proof. See infra note 85 . This type of presumption gives the defendant the benefit of the doubt, yet allows the prosecution to attempt to rebut the presumed characteristics.

Under this approach, the trial judge should decide as a matter of law that the presumed characteristics are not rebutted unless jurors could reasonably differ on whether the prosecution has met its burden. If jurors could reasonably differ, the jury should be imstructed that it must find the presumed fact established unless it is satisfied to the contrary by the appropriate standard of proof. See Assembly Comm. on Judiciary Comment on Cal. Evid. Code $\S 606$ (West 1966).

75. See Nation-Wide Check Corp. v. Forest Hills Distribs., 692 F.2d 214, 217 (1st Cir. 1982) (accepting certain characteristics about some docunents whieh plaintiffs sought to establish in a civil case); English v. 21 st Phoenix Corp., 590 F.2d 723, 727-29 (8th Cir.), cert. denied, 444 U.S. 832 (1979); People ex rel. Gallagher v. District Court, 656 P.2d 1287, 1293 (Colo. 1983) (court accepted the defendant's characterization of evidence); People v. Holloway, 649 P.2d 318, 320 (Colo. 1982) (appellate court permitted the trial court to explore the possibility of accepting the contents of destroyed evidence as claimed by defendant); see also Comment, supra note 13, at 564.

There is also statutory support for the "presumed fact" remedy in Federal Rule of Civil Procedure 37(b)(2)(A), which provides courts with the power to issue "[a]n order that the matters regarding which the order was made or any other designated facts shall be taken to be established for the purposes of the action in accordance with the claim of the party obtaining the order." FED. R. Civ. P. $37(\mathrm{~b})(2)(\mathrm{A})$. 
tion's description of the evidence or the defendant's testimony regarding the information contained in the lost or destroyed evidence. Neither alternative is completely satisfactory, however. Use of the prosecution's description is equivalent to adoption of the good faith/ normal procedures standard and its associated shortcomings. ${ }^{76}$ On the other hand, reliance on the defendant's testimony is arguably misplaced because it encourages the defendant to lie. Furthermore, the prosecution cannot prove the falsity of the defendant's claim since the evidence is unavailable.

Nonetheless, belief in the defendant's testimony is not entirely unjustified. It is indeed difficult to ascertain whether the defendant is lying. But an incorrect decision based upon such speculation could result in the conviction of an innocent person. ${ }^{77}$ Moreover, the prosecution's error has denied the defendant access to the itein which would have corroborated his claim and, therefore, credibility issues should be resolved in the defendant's favor. ${ }^{78}$ This greater reliance on the defendant's testimony will induce the prosecution to follow the high standards for preserving evidence set forth earlier in this Cominent. ${ }^{79}$

Yet the defendant's testimony alone cannot cover all situations. If the defendant is ignorant about the nature of the missing evidence, the court must decide how the lost or destroyed evidence might have been helpful to the defendant. The court can best nake this decision by

76. See supra text accompanying notes $18-26$.

77. Some courts have opted for resolving doubt in favor of the defense in inherently speculative situations. See, e.g., United States v. Tariq, 521 F. Supp. 773, 786 (D. Md. 1981) ("[I]n a criminal prosecution, where the Court inust speculate, it does so in the defendant's favor."); People v. Hawn, 99 Ill. App. 3d 334, 340, 425 N.E.2d 1024, 1028 (1981) ("Under circumstances such as these where this nost unfortunate occurrence may be 'attributable to either innocent or criminal cause, the innocent hypothesis will be adopted.' ") (quoting People v. Potter, 5 Ill. 2d 365, 372, 125 N.E.2d 510, 513 (1955)).

78. Nation-Wide Check Corp. v. Forest Hills Distribs., Inc., 692 F.2d 214, 218 (1st Cir. 1982) (the risk of an erroneous judgment should be put on the party that initially created the risk); People v. Moore, 34 Cal. 3d 215, 221, 666 P.2d 419, 422, 193 Cal. Rptr. 404, 407 (1983) (court's speculation as to the nuateriality of evidence in defendant's favor is acceptable because it is the government's loss of evidence that necessitated any kind of speculative inquiry at all).

Moreover, in a government-created situation where both sides are able to lie, resolving any doubt in favor of a defendant is consistent with the general philosophy underlying our legal system that it is better to let the guilty go free than to convict the innocent.

79. Courts have begun to acknowledge the utility of corrective relief in its deterrent capacity. See, e.g., Nation-Wide, 692 F.2d at 217-18 (court applied sanction of adverse inference in a civil case to deter similar behavior in the future); People ex rel. Gallagher v. District Court, 656 P.2d 1287, 1293 (Colo. 1983); Long v. State, 431 N.E.2d 875, 877 (Ind. Ct. App. 1982).

The deterrent impact of rentedies on law enforcentent entities lias been extensively explored in connection with the exclusionary rule. Though certainly not conclusive, the evidenee indicates that remedies such as the exclusionary rule do act as a deterrent. See, e.g., Canon, Is The Exclusionary Rule in Failing Health? Some New Data and a Plea Against a Precipitous Conclusion, 62 KY. L.J. 681, 697-717, 725-27 (1974); Kamisar, is the exclusionary rule an "illogical" or "unnatural" interpretation of the Fourth Amendment?, 62 JUDICATURE 66, $72-73$ (1978). 
looking to the substantive law of the case, the issues in the case, and by applying the evidentiary principles of relevance. ${ }^{80}$

For exaunple, in People v. Gonzales, ${ }^{81}$ the victim of an attenpted robbery managed to copy words tattooed on the robber's arn onto a piece of paper which he later gave to the police. The police subsequently lost the scrap of paper. Gonzales, who had the words "mot gulity" tattooed on his arn, was arrested and charged with attempted robbery. Without the paper the victim was unable to recall the words on the tattoo. When asked whether "guilty" seemed right, the victim said that the word was familiar though lie was able to recall positively only the first letter. ${ }^{82}$ The court rejected the government's argument that the officers inadvertently failed to notice the misspelling of the word on the piece of paper. ${ }^{83}$ To deter similar government conduct in the future, the court granted a new trial in whicl the jury was to be instructed that "it is conclusively established the . . robber's tattoo [consisted] of six letters, 'g-u-i-1-t-y.' "84

Under certaim circumstances, presumed characteristics may be rebutted in lost or destroyed evidence cases. For exainple, if evidence has been derived from a number of sources, the characteristics of the missing evidence inust be balanced against any otlier evidence tendimg to establish the nonexistence of those characteristics. If there is other evidence that clearly and convincingly demonstrates that the presumed characteristics of the lost or destroyed evidence are unwarranted, then these characteristics are rebutted..$^{85}$

80. See, e.g., Hatfield v. State, 663 P.2d 987, 991 (Alaska Ct. App. 1983) (defendants admitted stolen copper could not have been worth less than $\$ 50$ though they were uncertain whether it was worth as much as the government said it was worth. The court implicitly accepted that it was probably worth approximately $\$ 50$ and reduced the defendants' conviction accordingly).

81. 156 Cal. App. 3d 558, 203 Cal. Rptr. 38 (1984).

82. Id at 560, 203 Cal. Rptr. at 38-39.

83. Id at 562, 203 Cal. Rptr. at 40 .

84. Id. (empliasis in original).

85. Under current law, the degree of proof the government unust satisfy to rebut a presumption in the defendant's favor is unclear. Civil cases lave required differing burdens of proof, depending on the policies the presnmption was designed to advance. See CAL. EvID. Code \& 605 (West Supp. 1983); Assembly Comm. ON Judiciary CoMment on CAL. Evid. Code $\S 605$ (West 1966). For example, there is a strong presumption that any child born to a woman during her marriage is the legitimate offspring of lier husband. See, e.g., Bernheimer v. First Nat'l Bank, 359 Mo. 1119, 225 S.W.2d 745 (1949). To rebut such a presumption, most courts lave required the party against whom the presumption operates to produce clear and convincing evidence to the contrary. See, e.g., Hale v. State, 175 Md. 319, 2 A.2d 17 (1938); In re L-, 499 S.W.2d 490 (Mo. 1973); In re Lentz, 247 A.D. 31, 283 N.Y.S. 749 (1935); In re Gregoire's Estate, 156 Or. 111, 64 P.2d 1328 (1937). Some courts have even employed the "beyond a reasonable doubt" standard. See, eg., In re Jones' Estate, 110 Vt. 438, 8 A.2d 631 (1939). The policy of guaranteeing fair trials to defendants is at least as important as those policies pronoted by presumptions rcquiring clear and convincing rebuttal. The prosecution should therefore be reqnired to produce at least clear and convincing evidence to rebut any presumed characteristics. 
Drunk driving cases aptly illustrate the rebuttal of presumed characteristics. For exainple, assume that pursuant to the defendant's arrest, the police take a urine or blood test, and a breathalyzer test. The defendant may test the preserved urine or blood samples independently; however, the breathalyzer test cannot be run again. At trial, the prosecution introduces results from both tests, each of which shows the defendant's blood alcohol to be at an illegal level. The defendant, on the other hand, argues that if the breath sample were available, testing it would show that his blood alcohol level was within legal limits. Under the presumed characteristics reinedy, the court presumptively establishes that the lost or destroyed breath sample contamed less than the legal limit of alcohol. In this situation, however, retestable or verifiable evidence exists that indicates that the destroyed evidence would also have revealed an illegal level of blood alcohol. Therefore, the court may reasonably conclude that the presumed characteristics of the defendant's breath sample have been rebutted.

Rebuttal of the presumed characteristics is particularly warranted when mechamical instruments are involved. Although they may sometimes be inaccurate, their results are often independently verifiable. However, when dealing with live witnesses, courts must be extremely careful; individuals often make errors in perception and witnesses have been known to perjure themselves. This is not to say that if live witnesses are involved, presumed characteristics are conclusively estabhished. Rather, a court must be careful in allowing the testimony of witnesses to overcoine the presumption. Thus, issues of credibility must be thoroughly explored before the court determines whether the prosecution has overcome the presumption.

For example, suppose that in a transportation of illegal ahiens case, the government deports one of three illegal aliens. Two are still available to testify against the defendant. Although the ahens testify that the defendant knew they were illegally in the country, the defendant demies having this knowledge and claims that if the deported witness had been detained, he would support the defendant's position. Sucli a case is distimguishable from the drunk driving example: while the test results from the blood or urine sample are completely mechanical and dispassionate, the alien witnesses may be notivated by a number of outside influences, rendering their testimony less objective. For example, they may hie in the hope of obtaining lement treatment from the government.

In addition, to determine whether the presumption is rebutted, the testimony of the investigating officers or others responsible for safeguarding the evidence should never be allowed; otherwise the government could always justify any destruction or loss of evidence by putting 
its agents on the stand. The use of such testimony would foster difficulties identical to those under the good faith/normal procedures standard ${ }^{86}$ However, if the government introduces the testimony of independent third parties, or test results that can be independently verified by the defense, the presumed characteristics may be rebutted.

The presumed characteristics approach, if unrebutted, will always leave a defendant better off than without the evidence at all. For example, if results distilled from lost or destroyed items are the sole evidence used to convict him, a defendant nay claim that the evidence had certain presumed characteristics. ${ }^{87}$ However, establishment of certain characteristics about the circumstantial evidence is equivalent to acceptance of the defendant's ultimate conclusion of innocence only if no other imcriminatimg evidence exists. The presumed characteristics remedy properly concedes to the defendant only his explanation of the characteristics of the evidence, not his explanation of how the evidence tends to prove his innocence. Therefore, if other incriminating evidence exists, the reinedy does not automatically lead to dismissal; rather, the jury must balance the other evidence against the established characteristics of the missing evidence. The presumed characteristics remedy leads to a fair result because it does not award the defendant a result he could not have achieved had the evidence been present.

\section{CONCLUSION}

This Comment proposes a comprehensive approach for analyzing destruction or loss cases. First, the trial court must determine whether the evidence was lost or destroyed at the crime-scene or post crimescene stage. If the evidence was lost or destroyed at the crime-scene stage, the trial court must decide whether the potential significance of the evidence was such that it could reasonably have been expected to relate to the case. Relief for destruction or loss at the crime-scene stage should be granted only if the trial court concludes that a reasonable agent would have preserved the evidence. On the other hand, if the evidence was Iost or destroyed at the post crime-scene stage, the presumed characteristics remedy will be automatically applied unless the trial court determines that the prosecution has satisfactorily followed the notice-petition approach, affording the defense an adequate opportunity to examine the evidence prior to its destruction.

If the trial court determines relief is warranted, it will presumptively estabhish certain characteristics about the lost or destroyed evidence. These characteristics may be described by the defendant or, in

86. See supra text accompanying notes $\mathbf{1 8 - 2 6}$.

87. See People v. McCann, 115 Misc. 2d 1025, 1032, 455 N.Y.S.2d 212, 216-17 (1982). 
the absence of such a description, the court will presume characteristics about the evidence favorable to the defense under the substantive law of the case. The prosecution may then offer evidence, other than testimony by those responsible for the loss or destruction, to rebut the presumed characteristics.

If hittle or no rebuttal evidence is offered, the trial judge may rule as a matter of law that the presumed characteristics have been conclusively established. The jury then weighs these characteristics of the missing evidence against other incriminating evidence. Such characteristics may cast sufficient doubt in the jurors' minds to acquit the defendant. However, if reasonable jurors could differ as to whether the prosecution has produced clear and convincing evidence against the presumption, the issue inust go to the finder of fact. Nevertheless, the jury inust be carefully instructed that it is the prosecution's burden to clearly and convimcingly prove the nonexistence of the presumed characteristics.

The presumed characteristics approach strikes a fairer balance between the prosecution and defense. An accused should at least be able to examine both the evidence favorable to his defense and the evidence used to convict him. Regardless of the reason for the destruction or loss of evidence, the defendant has still been harmed; this unfairness is exacerbated if the government maliciously or negligently destroys the evidence. Unfortunately, fairness can only be achieved at a cost to society. And, in a world of scarce judicial resources, ideal fairness cannot be achieved. However, an adequate balance can be struck between the prosecution and defense. The duty to preserve evidence and the presumed characteristics approach dictate the shape that balance should take.

Che H. Lee*

- A.B. 1982, Occidental College; third-year student, Boalt Hall School of Law, University of California, Berkeley. 